\title{
Cost overruns, management problems found in British Antarctic projects
}

London. The British Antarctic Survey (BAS) received a public rebuke last week from the government's financial watchdog for its handling of several capital projects during the past few years.

The National Audit Office (NAO) complimented BAS on three of four projects and on the general quality of its research. But it criticized some of the procedures used, including those for the construction of a new research and supply vessel, the RRS James Clark Ross, and for an airstrip and berthing jetty at its Rothera station. The total cost has been several million pounds more than budgeted.

The budget of BAS, which is part of the Natural Environment Research Council, rose nearly fourfold, to $£ 52.4$ million (US\$75 million) in 1990-91, in the wake of the 1982 Falklands War following a decision by the then Prime Minister Margaret Thatcher to raise Britain's profile in the region. As a result, Antarctic science was one of the few research disciplines to receive a significant funding boost in the 1980s.

A large proportion of the new money has been spent to improve access for scientists. In addition to building the RRS James Clark Ross and the Rothera airstrip, BAS replaced its research station Halley, located on a fast moving ice-shelf, and bought a De Havilland Dash 7 aircraft, which was converted for Antarctic operation.

There were cost overruns on each project and also, in the last two cases, delays in completion. Design specifications for the research ship, for example, were still being finalized even after the design contract had been signed. Originally estimated to cost $£ 30$ million, the ship was budgeted at $£ 40.8$ million and wound up costing $£ 42.7$ million.

Similarly, inadequate information about the siting of the jetty at Rothera meant that it had to be redesigned and repositioned at a relatively late stage, at an additional cost of $£ 2$ million. BAS spent $£ 9.4$ million, $£ 3.4$ million more than planned, to rebuild Halley, and the project took two years longer than expected. In each case, according to the audit office, BAS devoted insufficient resources to project management and failed to train and support the project managers adequately. The project officer for the $R R S$ James Clark Ross, for example, lacked knowledge of ship construction and experience with large projects

BAS director David Drewry is withholding detailed comments on the criticisms until after parliament's public accounts committee has discussed the NAO's report next month. But he believes that "the report clearly indicates that, as far as taxpayers are concerned - and given the difficulties of operating in one of the most

\section{IMAGE UNAVAILABLE FOR COPYRIGHT REASONS}

ce was not the only obstacle to building the RS James Clark Ross.

hostile parts of the planet - they have had value for money". Drewry says that the problems with contract management were "second-order issues" and that the cost overruns have had little overall impact on the scientific programmes. However, he says that the points raised in the report have been "taken seriously" by BAS, whose experience should help other groups faced with similar challenges.

Meanwhile, BAS is due to announce this week how it intends to spend an extra $£ 4$ million awarded by the Office of Science and Technology over the next three years. A significant proportion of this sum will be used for clean-up operations required under the terms of the Antarctic Treaty signed in Madrid in 1991. Part of the money will also be used to refurbish the Signy research station.

The money is considerably less than the $£ 12$ million that BAS is reported to have requested and has raised fears that some research projects may be terminated. Drewry says that BAS intends to maintain its current level of scientific activity and that there are no plans for redundancies among BAS staff.

David Dickson

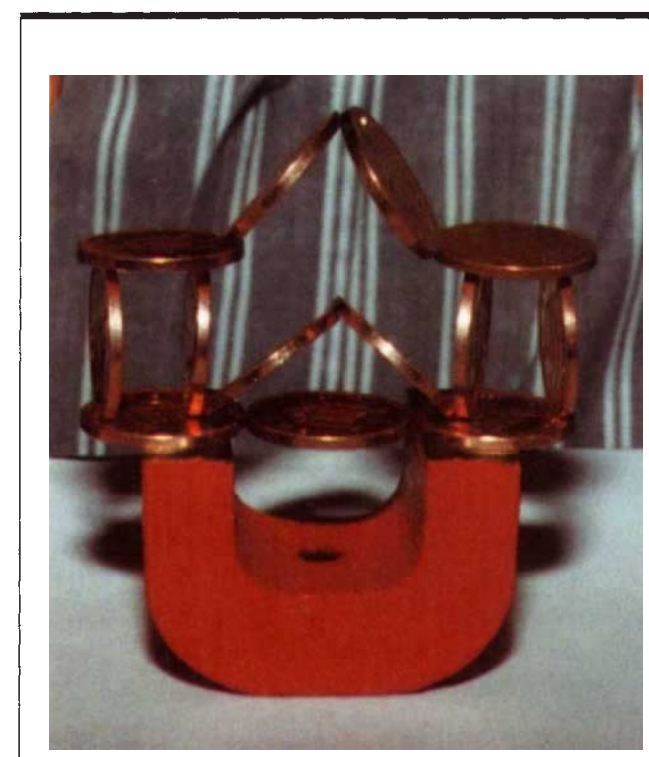

\section{Magnetic money}

London. The ever decreasing value of coinage is the common currency of taxi driver and bar talk, but a new cut-price penny with surprising magnetic properties is the sole interest of an international Magic Penny Society, founded by Robin Willson, professor of Biochemistry at Brunel University.

Last September the Royal Mint stopped making penny and twopenny coins from bronze and started instead to electroplate steel disks with copper. Willson first knew of this when one of the coins stuck to his magnetic key-retainer - the steel core is a soft magnet that becomes magnetized in an applied field. Fields minimize their energy

by funnelling through the coins, which consequently stick together.

Initially, Willson used the effect to entertain children at the leukaemia unit in St Bartholomew's hospital, but when he found that scientists also were taking interest, he founded the Magic Penny Society, partly because he sees the new pennies as an excellent educational toy to excite children's interest in science.

Already featured at the British Science Museum, the Bristol Exploratory, in

Singapore (where one onlooker built the penny pagoda, above), and even with one of Faraday's original electromagnets at the Royal Institution, the clever currency will next appear at the Edinburgh Science Festival next week.

Roland Pease 